\title{
Looking back, moving forward: Access to antiretroviral therapy for HIV infected adults and children in developing countries: Horizons Studies, 2002 to 2008
}

Avina Sarna

Population Council

Scott E. Kellerman

Population Council

Follow this and additional works at: https://knowledgecommons.popcouncil.org/departments_sbsr-hiv

Part of the Demography, Population, and Ecology Commons, Family, Life Course, and Society

Commons, International Public Health Commons, and the Medicine and Health Commons

How does access to this work benefit you? Let us know!

\section{Recommended Citation}

Sarna, Avina and Scott E. Kellerman. 2010. "Looking back, moving forward: Access to antiretroviral therapy for HIV infected adults and children in developing countries: Horizons Studies, 2002 to 2008," Horizons Synthesis Background Papers. Washington, DC: Population Council. Version of record: https://doi.org/10.1177/003335491012500221 


\section{LOOKING BACK, MOVING FORWARD}

\section{Access to Antiretroviral Therapy for HIV InfeCted Adults ANd ChILdRen IN Developing Countries}

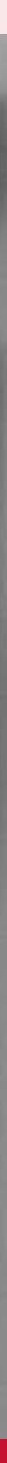

\section{HORIZONS StUDIES 2002 TO 2008}




\section{Hgrizons}

In 1997, the Population Council initiated the Horizons Program—a decade-long USAID-funded collaboration with the International Center for Research on Women, the International HIV/AIDS Alliance, PATH, Tulane University, Family Health International, and Johns Hopkins University—designing, implementing, evaluating, and expanding innovative strategies for HIV prevention and care.

Horizons developed and tested ways to optimize HIV prevention, care, and treatment programs; worked to reduce stigma and improve gender-biased behaviors; and greatly expanded knowledge about the best ways to support, protect, and treat children affected by HIV and AIDS. In all its projects, Horizons strengthened the capacity of local institutions by providing support and training to colleagues.

This series of synthesis papers presents lessons learned and best practices on six key topics that Horizons investigated: HIV-related stigma, access to antiretroviral therapy, men who have sex with men, orphans and vulnerable children, HIV and sender, and prevention of mother-to-child transmission of HIV. 


\section{Access to Antiretroviral Therapy for HIV INFECTEd ADULTS AND CHILDREN IN Developing Countries}

The advent of life-saving antiretroviral therapy (ART) for people living with HIV in the late 1990 s promised to avert millions of deaths to AIDS. However, in resource-constrained settings hard hit by the epidemic, providers and people living with HIV faced numerous challenges to the effective delivery and uptake of treatment services. In 2001, Horizons began its investigation of the rollout and provision of ART in Asia and Africa in order to answer key questions surrounding service delivery, health seeking behaviors, adherence, cost, and barriers to treatment for HIV-infected adults and children. Horizons researchers found that provision of and adherence to ART regimens is hindered by a lack of knowledge among providers and affected communities, a lack of linkages between key services, and by stigma surrounding HIV. Our research has been used to break down these barriers and to guide global efforts toward ensuring full access and adherence to treatment across diverse settings.

\section{Introduction}

In the late 1990 s, increased accessibility of life-extending antiretroviral therapy (ART) changed the face of the AIDS epidemic around the world. Although Brazil, Thailand, Senegal, and Botswana were providing ART for adults through public sector health facilities as early as 2000 , government treatment programs in other countries hard hit by HIV in the developing world were not established until 2002 or later. ART services for children were started even later. Program managers in low resource settings rapidly raised questions regarding the best way to roll-out treatment programs: What were the key elements of health care readiness needed to offer ART services? What was the best way to train staff providing services? And what could be done to promote adherence to therapy? There was virtually no relevant evidence to answer these questions.

To respond to these questions, the Horizons Program convened a meeting of international experts in 2001 to explore the operational challenges related to the introduction of therapy in developing country settings and to prioritize research questions around access to ART [1]. Following this meeting Horizons embarked on a research program that eventually included 11 projects (Appendix) across Asia and sub-Saharan Africa examining service delivery, health 
seeking behaviors, adherence, cost and other factors affecting treatment for HIV-infected adults and children. The design and implementation of these studies raised additional questions regarding stigma, quality of life, and sexual risk behaviors among persons living with HIV on ART. This paper summarizes the key findings and lessons learned from these projects and provides recommendations for evidencebased programming and future research around treatment for both children and adults.

\section{Lack of Provider Readiness, Community Awareness, Reduce Uptake and Adherence}

Horizons initially undertook exploratory studies to document the experiences of programs that had already initiated ART services. These studies identified patient retention and adherence to treatment as major challenges for scale-up. For example, a 2002 situation analysis of the newly implemented Thai national ART program in 15 hospitals in five northern provinces documented a drop-out rate of 30 percent in the first six months of the program, primarily because of side effects and lack of on- going support. Types of non-adherence varied, including missed doses, not taking medications on time, and not following treatment instructions.

A 2004 Horizons study of people living with HIV in India found adherence to be significantly lower among patients with severe depression. Adherence was also lower among those receiving free ART compared to patients in the private sector who paid out-of-pocket for treatment. The study highlighted the need for better patient education before initiating and during ART $[2,3]$.

Horizons' research also revealed gaps in provider training, confidence, and competency, which often prevented them from delivering ART services. In Thailand, a majority of ART providers (i.e., doctors, nurses, and counselors) said they had trouble counseling patients on drug side effects (Table 1). Nearly half of doctors reported difficulties in diagnosing and managing side effects and drug interactions, despite receiving intensive training [4].

In a pediatric study in three Kenyan provinces selected because of high HIV prevalence and the availability of pediatric HIV care services,

Table 1 Number and percentage of care providers who had difficulties in providing Access To Care Project services in northern Thailand (2002)

\begin{tabular}{lccccc}
\hline Item & $\begin{array}{c}\text { Doctors } \\
\text { n/N }\end{array}$ & $\begin{array}{c}\text { Nurses } \\
\mathrm{n} / \mathrm{N}\end{array}$ & $\begin{array}{c}\text { Pharmacists } \\
\mathrm{n} / \mathrm{N}\end{array}$ & $\begin{array}{c}\text { Counselors } \\
\mathrm{n} / \mathrm{N}\end{array}$ & $\begin{array}{c}\text { Total } \\
\mathrm{n} / \mathrm{N}(\%)\end{array}$ \\
\hline $\begin{array}{l}\text { Diagnosis and management of } \\
\text { side effects }\end{array}$ & $3 / 7$ & $4 / 11$ & $3 / 8$ & & $10 / 26(38)$ \\
Management of drug interaction & $3 / 7$ & $1 / 7$ & $2 / 7$ & & $6 / 21(28)$ \\
Counseling on drug side effects & $5 / 6$ & $14 / 18$ & $6 / 10$ & $3 / 4$ & $28 / 38(74)$ \\
Interpreting laboratory results & $1 / 7$ & $5 / 13$ & $2 / 4$ & & $8 / 24(33)$ \\
$\begin{array}{l}\text { Management of opportunistic } \\
\text { infections }\end{array}$ & $2 / 8$ & $1 / 6$ & & & $3 / 14(20)$ \\
\hline
\end{tabular}

Note: $N=$ number of care providers who responded to the question, $n=$ number of those who had difficulties. 
health workers revealed knowledge gaps and low confidence regarding pediatric HIV diagnosis protocols, calculating medication dosages, management of multiple illnesses, prevention of mother-to-child transmission of HIV (PMTCT), and counseling [5]. A lack of standardized or coordinated training for health care workers on the management of pediatric HIV was also identified in South Africa, where most doctors and nurses reported receiving no formal training in ART, instead using self-study from books and online courses [6].

A study exploring practices in pediatric ART rollout at 16 sites in five South African provinces found that nearly all of the children receiving ART were referred from community clinics or from inpatient wards. The vast major-
-Doctor (in a peri-urban setting) interviewed for a study of pediatric HIV treatment in South Africa ity of children had been tested for HIV because they were chronically ill or hospitalized with a serious illness (Figure 1). Less than 2 percent of children receiving treatment were referred from PMTCT programs [6].

The lack of follow-up care from PMTCT programs was particularly notable. A study of HIV-positive pregnant and post-partum women in three high prevalence Indian states found that less than one-third had been informed about CD4 testing, and only 18 percent were informed about the availability of ART during antenatal care. Of the women with living children, 44 percent reported that none of their children had been tested for HIV [7].

The Kenya pediatric study also included a community survey of primary caregivers of children [5]. The study found that while caregivers understood the basics of HIV in adults, knowledge about HIV infection and symptoms in children was low. Only half could name three symptoms indicative of pediatric HIV infection. Although the majority were aware of treatment options for HIV-infected children and believed that these children could live into adulthood, less than two-thirds knew where to access HIV testing and treatment services for children [5]. Health care costs (including those related to transport, consultation fees, and medications) and HIV-related stigma also kept people from seeking care. 


\section{Frequent Clinic Visits, Enhanced Counseling, Support Adherence}

Directly observed therapy (DOT) is a treatment strategy originally developed for tuberculosis patients, who must take all their medications consistently and on time for up to nine months to rid themselves of the infection. In the standard DOT approach, health workers or community volunteers watch clients as they take their medication. One big difference between treatments for $\mathrm{TB}$ and HIV is that antiretroviral medications for HIV must be taken for life. A DOT strategy for AIDS treatment is called DAART, for "directly administered antiretroviral therapy." A DAART program includes observation of patients taking their medications, but less often than for TB.

To develop a DAART program, Horizons researchers explored the acceptability of home visits by health care workers versus clinic visits among people with HIV, their preferred frequency of clinic visits per week, as well as the type of health worker they preferred for home visits. The majority of people interviewed preferred clinic-based DAART, citing confidentiality concerns and risk of stigma within the community associated with home health visits. Clients also believed that clinic visits afforded access to qualified health care workers and felt a sense of personal control by visiting the clinic instead of being visited at home [8].

Building on this research, acceptability of a clinic-based approach to

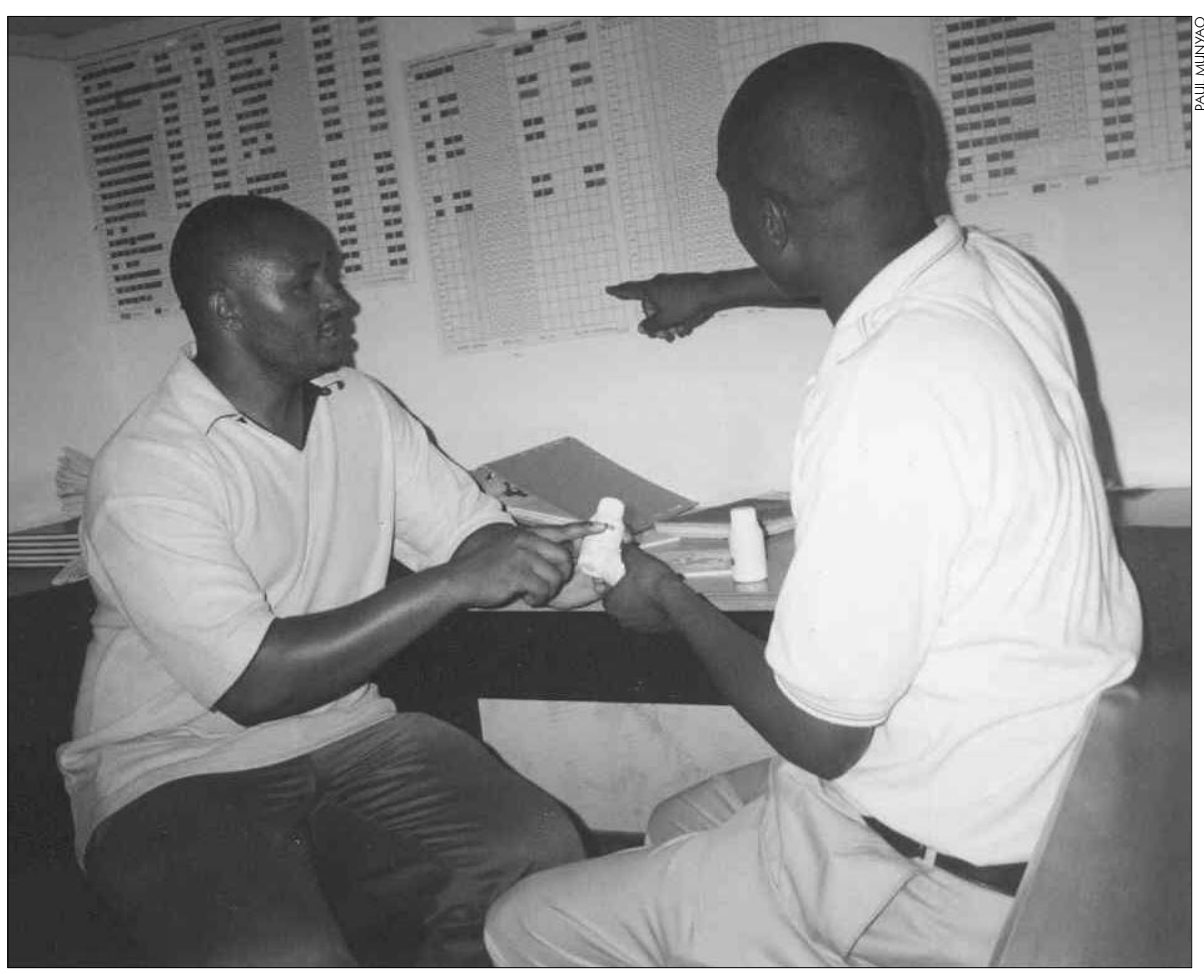

Horizons researchers in Kenya found that DAART clients preferrred clinic-based visits with health workers over home-based visits due to confidentiality concerns and fear of stigma.
DAART to promote adherence to ART was assessed among HIV-infected persons accessing services in coastal Kenya [9]. Horizons conducted one of the first randomized, controlled studies of a clinic-based, DAART intervention as a strategy to increase adherence to ART in a resource-constrained setting in Kenya. The intervention consisted of twice weekly clinic visits for the first 24 weeks where patients met with DAART nurses who watched them taking their medicine, gave them more medications for the time between visits, counted pills, and counseled them on ways to continue taking their medication properly. Patients not getting DAART received standard monthly in-clinic follow up, including counseling on taking medicine properly, and routine healthcare [10]. 
The study found that DAART was feasible and effective in helping patients take their medicine properly during the intervention period (Proportion with > 95\% adherence: DAART: 92 percent vs. non-DAART: 80 percent; $\mathrm{p}=$ 0.012 ), but these effects were not sustained after the intervention $[8,11]$. DAART was found to be particularly beneficial in patients with moderate or severe depression in the first 24 weeks. The study findings raise further questions about the best way to optimize DAART and whether it is most effective amongst a sub-group of adults at risk for not taking their medicines properly [11].

In Thailand, Horizons researchers conducted a randomized controlled study to evaluate interventions to help people take their antiretroviral medications properly and reduce drop-outs at 45 hospitals across four northern provinces [12]. Hospitals were assigned to three groups: (1) enhanced adherence counseling, including patient education, side effect management, and integration of medication into daily life; (2) enhanced adherence counseling plus peer edu-

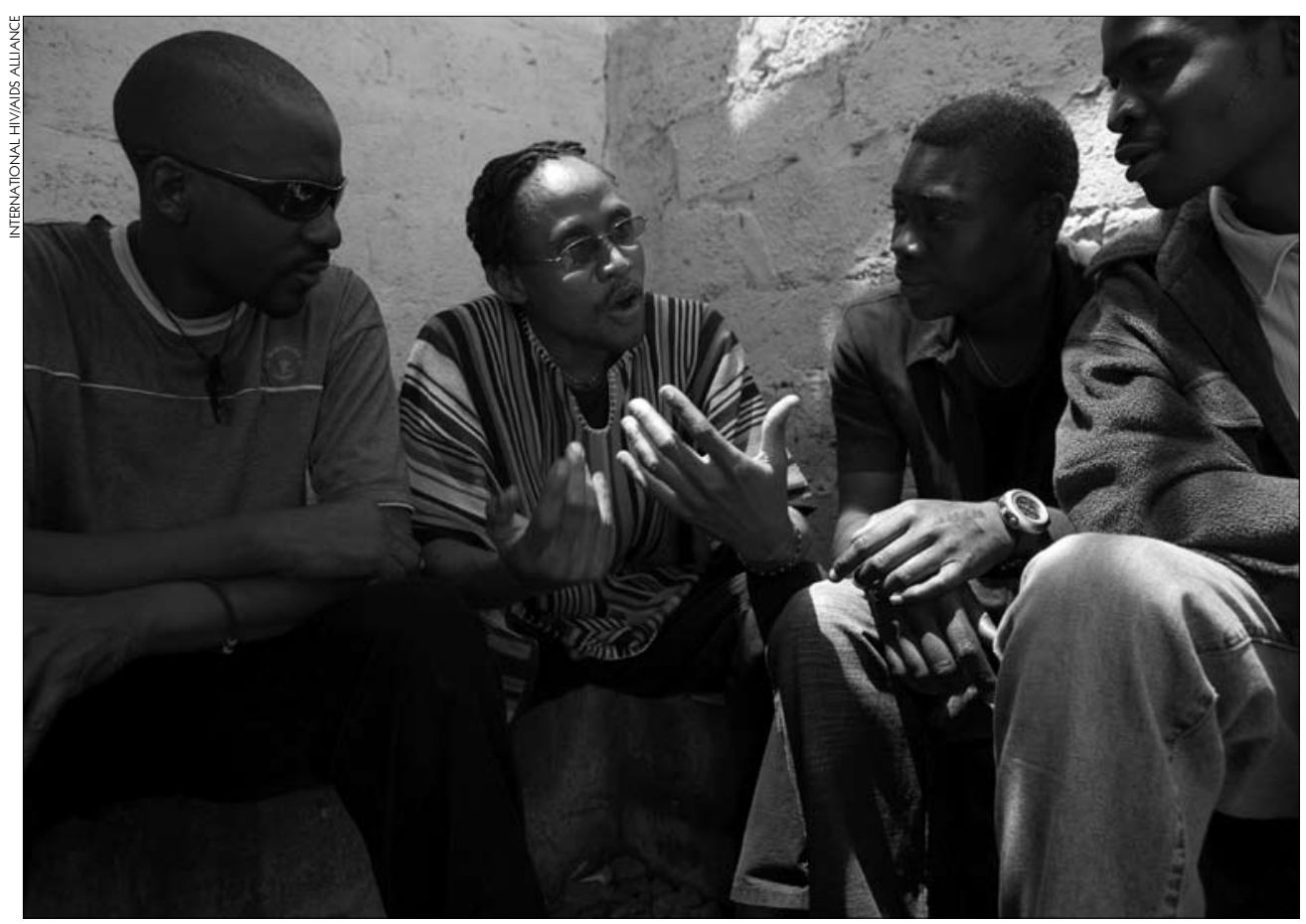

Horizons researchers explored the impact of the AIDS Community and Education and Referral Strategy (ACER) in Zambia. Here, a treatment support worker talks to community members. cation at clinic and home visits; or (3) standard care consisting of routine counseling and clinical follow up. The study found that enhanced counseling with and without peer involvement was effective in reducing drop-outs compared with standard care at 12 months, and that at 12 months the peer intervention served to significantly increase patients' belief in their ability to take their ART properly [12].

\section{Involving Community, Helping Individuals}

While clinic-based interventions designed to increase an individual's adherence to the ART regimen are important, effective communitylevel interventions may also result in positive outcomes for people living with HIV. The AIDS Community and Education and Referral Strategy (ACER), in the Zambian cities of Lusaka and Ndola, represents one such effort. The intervention aimed to raise community awareness of HIV; strengthen communitybased support groups for people living with HIV by incorporating traditional healers, church groups, and homebased care services; establish referral mechanisms between health facilities and the community; and used volunteer peer treatment-support workers at clinics [13]. A Horizons evaluation found few significant differences in knowledge of HIV, disclosure of HIV status, and adherence to ART between communities that experienced the program and those that did not. It is likely that an unrelated clinic-based ART adherence program that was introduced in the comparison sites by another organization diluted the effects of the ACER intervention. 


\section{Impact of ART on People Living with HIV}

\section{Stigma}

Horizons researchers nested observational studies within intervention studies to examine change in HIV-related stigma among people with HIV who were receiving ART. These studies used an adapted HIV stigma scale covering four domains: personalized stigma, concerns about revealing their HIV status, negative self-image, and concern with public attitudes [14]. Common themes from Horizons studies in Thailand [12], Zambia [13], and Kenya

[15] showed that stigma decreased over time on ART. For example in Kenya the proportion of patients receiving ART reporting moderate to high stigma declined from 73 percent prior to initiating ART to 56 percent after 12 months of treatment (Figure 2). Internalized stigma appeared to be higher among female patients compared to male patients prior to initiating ART in Kenya [15] and Zambia [13].

\section{Perceived quality of life}

Perceived quality of life is a proxy for effectiveness of medication regimens; if HIV is effectively controlled, individuals have an increased sense of well-being and engagement in routine activities. Horizons' researchers documented significant increases in quality of life measures over time among ART clients.

In Thailand, significant improvements in mental and physical health scores over 12 months following counseling for antiretroviral medication adherence and peer support were observed among patients in ART programs [12]. In Kenya, significant improvements occurred across general health perception; physical, so- cial, and cognitive functioning; pain; mental health; and energy and fatigue.

\section{Gender}

Horizons studies noted gender differentials in patient populations: more than 60 percent of Kenyan and Zambian patients and more than half of Thai patients were female [11-13]. Of note, no gender differentials in adherence to drug treatment were documented.

\section{Sexual risk behavior}

Researchers have expressed concern that effective treatment and the increases in well-being and sexual activity that accompany it could lead to an increase in unprotected sex among people with HIV. Horizons research found no evidence of increased sexual risk behavior (i.e., multiple partners or unprotected sex) in Kenya [16-18], Thailand [19], Zambia [13], or India [3]. For example, in Kenya the proportion of sexually active participants who reported unprotected sex with an unknown or HIV-negative partner declined from 50 percent at baseline to 28 percent after 12 months on 
treatment (Figure 3). However, unprotected sex is still prevalent, underscoring that the risk of HIV transmission remains, particularly with regular partners.

\section{Testing and Validating Research Methods}

Horizons used a diverse range of research methodologies and study designs in its portfolio of research on access to treatment (Appendix).

This includes measures and scales that were previously tested and validated, particularly those pertaining to adherence to antiretroviral drug regimens [20], depression [21], and quality of life $[22,23]$. In some studies, scales were adapted by a team of expert psychologists and social scientists to more accurately reflect the local cultural context, and translations and back translations were pretested before application.

In the absence of a gold standard, measuring adherence to antiretroviral drug regimens accurately is a challenge especially in resourcelimited settings. We recognize that patients often overstate their adherence to drug regimens and under-report missed doses [24, 25]. Adherence studies often require that measures such as pill counts and self reports are undertaken by clinic staff as a part of clinical management. Specialized training for interviewers to ensure consistent and accurate data collection with regard to these measuring techniques is essential. Newer methods such as computerized pill counts and audio computer-assisted self-interviewing (ACASI) need to be explored further.

\section{Moving Forward}

Horizons was among the first research programs to implement intervention studies on antiretroviral medication adherence in developing countries. The evidence base provided by Horizons' early exploratory studies has contributed to the design, strengthening, and expansion of ART services. Horizons identified training gaps and a lack of provider confidence across several studies. Most treatment programs provide one-time, intensive provider training at their start. The importance of ongoing, needbased, and interactive training for providers cannot be overemphasized. Training materials, such as the adherence counseling manual developed by Horizons and used in Kenya [8], are important in this endeavor, and have since been

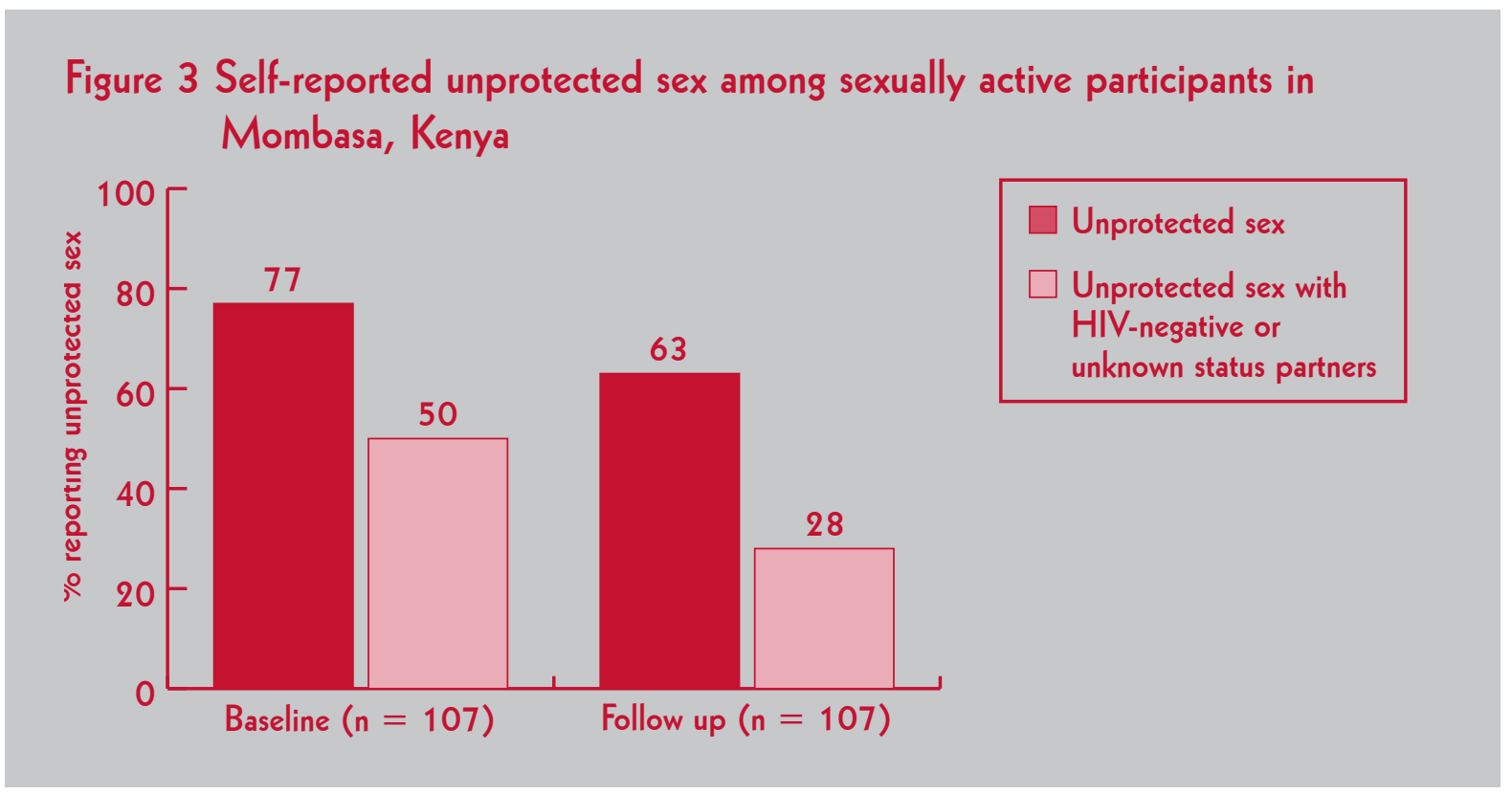


adapted by programs in Zambia, Tanzania, South Africa, and Russia.

Human resource shortages in Africa are well documented [26], and some treatment programs are run by clinical officers and nurses instead of medical doctors. Expert consultation is needed as treatment regimens become more complicated. Future research will be needed to evaluate models of training programs with ongoing mentoring and access to specialist services.

Horizons' research has highlighted the lack of integration among services for HIV testing, TB testing, the prevention of mother-to-child transmission of HIV, maternal health, and ART. This information has been used by program managers and departments of health, for example, in South African program planning efforts. In Kenya, the Kenya Network of Women with AIDS (KENWA) is developing interventions to increase community awareness of pediatric HIV and treatment. Efforts to integrate HIV prevention care and treatment services into existing maternal and child health services require evaluation to identify best practices and successful models for scale-up. As programs race towards universal access to ART, it is imperative to explore new approaches to service delivery while simultaneously strengthening health systems and monitoring quality of services.

DAART as a strategy to promote adherence has been evaluated largely among people who have HIV and are at risk of not taking their medications properly, such as injecting drug users [2729], patients in prison [30,31] and to a limited extent among the general population $[32,33]$. Horizons has added to the scientific evidence by rigorously evaluating clinic-based DAART in a resource-limited setting. Given that improvements in adherence were not sustained beyond the DAART intervention, further research is needed to determine the optimum duration of the intervention and ways to sustain its effects. This includes evaluating DAART among clients who have not taken their antiretroviral medications properly over time, a population for whom this resource-intensive intervention might prove most beneficial.

HIV programs have long used HIV-positive peers in developing countries as part of HIVprevention programs, for social support, and, to a limited extent, for treatment-related activities. However, before the mid-2000s there was no evaluation of a peer-based program designed to support people in taking their HIV drugs correctly. The Thailand Horizons study was one of the first to show that such interventions are more effective than standard care in increasing people's belief in their ability to take their drugs correctly, lowering self-stigma, and improving quality of life. This intervention has been introduced widely across the country with Global Fund assistance. Such interventions are costlier than traditional standard of care, and current scale-up of ART programs may exclude such ancillary services. Still, Horizons work in Kenya and Thailand showed the value of ancillary services, including, DAART and peer education and support.

Horizons studies were undertaken as ART programs first rolled out, and most patients presented with advanced HIV disease, a factor that undoubtedly stimulated adherence. As the epidemic matures, programs are increasingly managing patients on long-term treatment with emerging evidence of poor adherence to drug regimens [34]. Patients in resource-poor settings will experience side effects and other conditions associated with long-term ART, as has been documented in western countries [3, 35-37]. These include diabetes and lipodystrophy, a redistribution of fat tissue on the body. It is not uncommon for people on long-term antiretroviral treatment, for example, to have gaunt faces and/or a "hump" on the back of their neck. Second-generation drug adherence studies in developing countries will need to examine these factors, as well as viral resistance, and their intersection with quality of life and stigma. For example, lipodystrophy might 


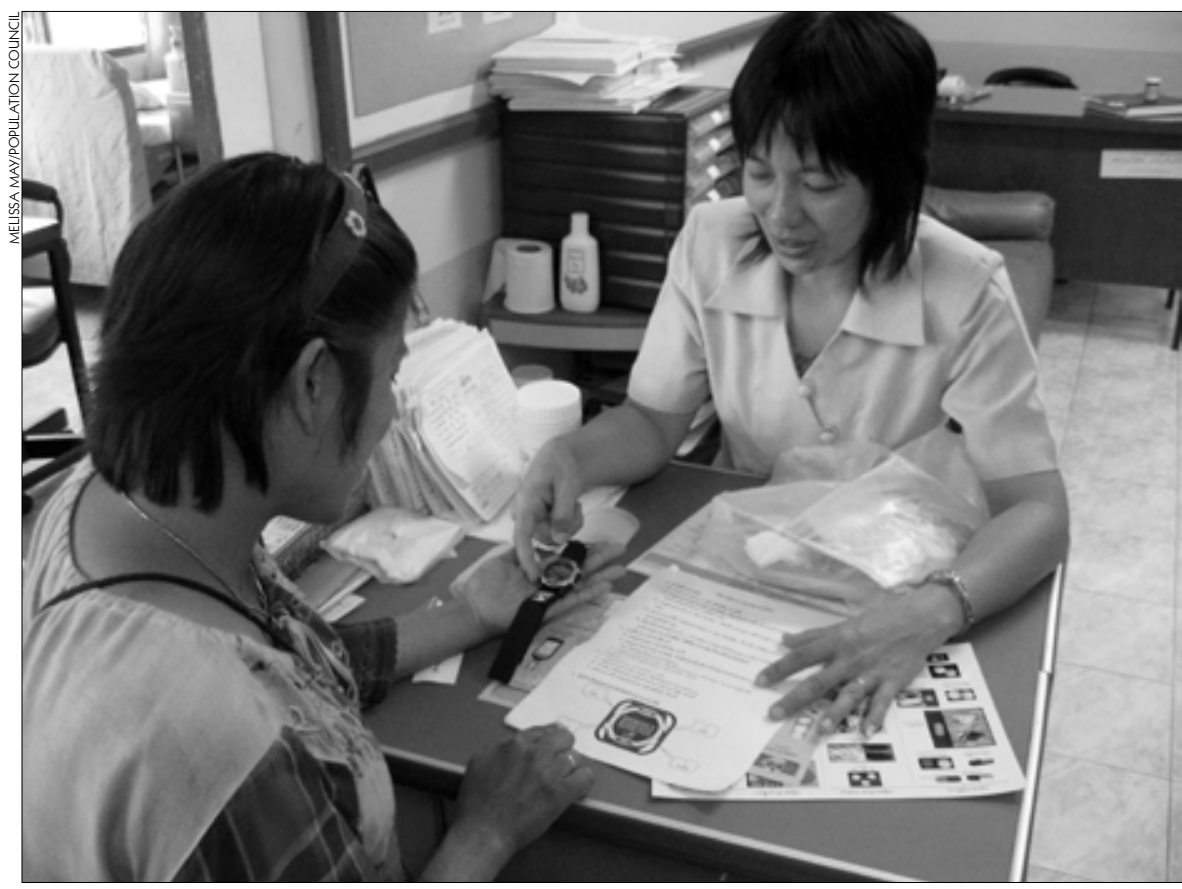

A Horizons study in Chang Mai emphasized the need for improved data collection methods and tools to measure adherence to drug regimens. interventions to increase the use of pediatric HIV testing and treatment services in Kenya, and has worked in South Africa on a family-centered approach to expand HIV testing of children and the provision of pediatric care and treatment. Drug adherence programs for pediatric populations need to be developed and evaluated in Africa as more HIV-infected children receive treatment. Age is also an important consideration, as young children, adolescents, and emancipated minors will have differing abilities to take their medications correctly.

Horizons' intervention studies also underscored the challenges of conducting operations research in field settings. Of particular importance is the need for improved data collection methods and tools to accurately measure drug regimen adherence.

serve as an identifier for HIV-positive individuals in the community, resulting in stigma and discrimination.

Although Horizon's studies provided no evidence of an increase in sexual risk behavior among people with HIV who are on treatment, unprotected sex in regular partner relationships is prevalent, and the risk of HIV transmission is still a concern. Treatment programs need to emphasize risk reduction, condom use, and partner testing. Population Council researchers developed a "prevention with positives" intervention to integrate prevention and treatment services in Kenya to address these issues.

Despite intense recent attention to pediatric treatment, access to treatment for HIV infected children has lagged behind that for adults [38, 39]. Priority areas for research have included evaluation of interventions to increase diagnosis of HIV among children and to facilitate early treatment for HIV-infected children. The Population Council is supporting community

\section{Horizons' partners at Chiang Mai University} crease the accuracy of pill counts; such methods need to be evaluated. ACASI has been used in other Population Council studies addressing sensitive topics and could be applied to treatment research in order to improve the accuracy of self-reports of adherence. Selecting HIV-infected patients to participate in studies is challenging as people with HIV cannot be identified or reached in communities for reasons of confidentiality. Horizons' researchers had to use convenience or quota sampling to overcome this problem [40]. Lastly, as in other sectors, sustaining interventions after initial funding ends is a challenge for both programs and researchers. For example, peer volunteers or community health workers play a key role in enhancing service delivery, but may require some form of compensation to continue delivering interventions.

Global efforts to expand access to HIV treatment in low- and middle-income countries developed a computer-based program to in- 
have resulted in significant progress. An estimated 42 percent of the 9.5 million people in need of ART had access in 2008 [41]. While positive, this figure reflects the monumental task ahead to achieve universal access by 2015 . Horizons' research has made major contributions to the body of scientific evidence about ART provision and adherence, has answered key research questions, and has provided directions for next steps to reach universal access. 


\section{APPENDIX}

\section{Sample characteristics and study design among Horizons studies, 2002-2008}

\begin{tabular}{|c|c|c|c|c|c|}
\hline Study title and country & $\begin{array}{l}\text { Year of } \\
\text { study }\end{array}$ & $\begin{array}{c}\text { Target } \\
\text { population }\end{array}$ & Sample size & $\begin{array}{l}\text { Type of } \\
\text { study }\end{array}$ & $\begin{array}{l}\text { Sampling } \\
\text { methodology }\end{array}$ \\
\hline $\begin{array}{l}\text { A rapid situation analysis of } \\
\text { the provision of highly active } \\
\text { antiretroviral therapy to persons } \\
\text { living with HIV/AIDS by the } \\
\text { Ministry of Public Health's Access } \\
\text { to Care Project in Northern } \\
\text { Thailand }\end{array}$ & 2002 & $\begin{array}{l}\text { HIV infected } \\
\text { adults }\end{array}$ & $\begin{array}{l}15 \text { ART clinics } \\
120 \text { PLHA }\end{array}$ & $\begin{array}{l}\text { RSA } \\
\text { Descriptive }\end{array}$ & Purposive sampling \\
\hline $\begin{array}{l}\text { Formative assessment of the } \\
\text { acceptability of modified DOT } \\
\text { strategy to promote adherence to } \\
\text { ART among PLHA in Mombasa, } \\
\text { Kenya9 }\end{array}$ & 2002 & $\begin{array}{l}\text { HIV infected } \\
\text { adults }\end{array}$ & 38 PLHA & $\begin{array}{l}\text { Qualitative } \\
\text { Descriptive }\end{array}$ & Purposive sampling \\
\hline $\begin{array}{l}\text { Reproductive health services in } \\
\text { KwaZulu Natal, South Africa: A } \\
\text { situation analysis study focusing on } \\
\text { HIV/AIDS services }{ }^{42}\end{array}$ & $\begin{array}{l}2002- \\
2003\end{array}$ & $\begin{array}{l}\text { HIV infected } \\
\text { adults }\end{array}$ & $\begin{array}{l}98 \text { health facilities } \\
418 \text { clients } \\
299 \text { health providers }\end{array}$ & $\begin{array}{l}\text { RSA } \\
\text { Descriptive }\end{array}$ & $\begin{array}{l}\text { Simple random sampling } \\
\text { of health facilities } \\
\text { Convenience sampling of } \\
\text { respondents }\end{array}$ \\
\hline $\begin{array}{l}\text { Operations research around the } \\
\text { introduction of antiretrovirals in } \\
\text { the management of HIV infected } \\
\text { individuals in Mombasa, Kenya } a^{8,10,} \\
11,15-18\end{array}$ & $\begin{array}{l}2003- \\
2006\end{array}$ & $\begin{array}{l}\text { HIV infected } \\
\text { adults }\end{array}$ & 234 PLHA & $\begin{array}{l}\text { Prospective } \\
\text { Randomised } \\
\text { controlled study } \\
\text { ( } 2 \text { arms) }\end{array}$ & $\begin{array}{l}\text { Quota sampling with } \\
\text { randomized assignment }\end{array}$ \\
\hline $\begin{array}{l}\text { Assessment of adherence to } \\
\text { treatment and sexual risk behaviour } \\
\text { among HIV-positive patients } \\
\text { receiving antiretroviral therapy_A A } \\
\text { diagnostic study in India }{ }^{3,4}\end{array}$ & 2004 & $\begin{array}{l}\text { HIV infected } \\
\text { adults }\end{array}$ & $\begin{array}{l}310 \text { PLHA on } \\
\text { treatment }\end{array}$ & Descriptive & Quota sampling \\
\hline $\begin{array}{l}\text { Community education and } \\
\text { referral: Supporting adherence } \\
\text { to antiretroviral treatment and } \\
\text { prevention for people with HIV in } \\
\text { Zambia }^{13}\end{array}$ & $\begin{array}{l}2004- \\
2007\end{array}$ & $\begin{array}{l}\text { HIV infected } \\
\text { adults }\end{array}$ & $\begin{array}{l}1,200 \text { community } \\
\text { members } \\
500 \text { PLHA on } \\
\text { treatment }\end{array}$ & $\begin{array}{l}\text { Prospective } \\
\text { Pre- and post- } \\
\text { intervention control } \\
\text { evaluation }\end{array}$ & $\begin{array}{l}\text { Cluster sampling of } \\
\text { community members from } \\
\text { households } \\
\text { Quota sampling of } \\
\text { PLHA }\end{array}$ \\
\hline
\end{tabular}




\begin{tabular}{|c|c|c|c|c|c|}
\hline $\begin{array}{l}\text { Reducing drop-outs and increasing } \\
\text { adherence-rates among persons } \\
\text { living with AIDS (PLA) on } \\
\text { antiretroviral therapy (ART) in } \\
\text { northern Thailand }^{12}\end{array}$ & $\begin{array}{l}2004- \\
2007\end{array}$ & $\begin{array}{l}\text { HIV infected } \\
\text { adults }\end{array}$ & $\begin{array}{l}45 \text { hospitals } \\
753 \text { PLHA }\end{array}$ & $\begin{array}{l}\text { Randomized } \\
\text { controlled study } \\
\text { ( } 3 \text { arms) }\end{array}$ & $\begin{array}{l}\text { Convenience sampling } \\
\text { of facilities with random } \\
\text { assignment to groups } \\
\text { Quota sampling of } \\
\text { PLHA }\end{array}$ \\
\hline $\begin{array}{l}\text { Exploring current practices in } \\
\text { pediatric ARV rollout and } \\
\text { integration with early childhood } \\
\text { programs in South Africa: A rapid } \\
\text { situation analysis } 6^{6}\end{array}$ & 2005 & $\begin{array}{l}\text { HIV infected } \\
\text { children }\end{array}$ & $\begin{array}{l}16 \mathrm{ARV} \text { programs } \\
126 \text { caregivers } \\
74 \mathrm{HCW}\end{array}$ & $\begin{array}{l}\text { RSA } \\
\text { Descriptive }\end{array}$ & Convenience sampling \\
\hline $\begin{array}{l}\text { Diagnostic operations research to } \\
\text { inform the national initiative on } \\
\text { improving access to treatment, } \\
\text { care and support for HIV-positive } \\
\text { women and their families in India }{ }^{7}\end{array}$ & $\begin{array}{l}2005- \\
2006\end{array}$ & $\begin{array}{l}\text { HIV infected } \\
\text { pregnant or } \\
\text { post partum } \\
\text { (<24 months) } \\
\text { women }\end{array}$ & $\begin{array}{l}315 \text { HIV infected } \\
\text { females }\end{array}$ & Descriptive & Convenience \\
\hline $\begin{array}{l}\text { Exploring models of delivering ART } \\
\text { and integration of ART with TB } \\
\text { services in South Africa }{ }^{43}\end{array}$ & 2006 & $\begin{array}{l}\text { HIV infected } \\
\text { adults }\end{array}$ & $\begin{array}{l}14 \text { health facilities } \\
262 \text { PLHA } \\
43 \text { health providers }\end{array}$ & $\begin{array}{l}\text { RSA } \\
\text { Descriptive }\end{array}$ & Convenience sampling \\
\hline $\begin{array}{l}\text { Healthy Start Pediatric HIV Study: } \\
\text { A diagnostic study investigating } \\
\text { barriers to HIV treatment and care } \\
\text { among children in Kenya }{ }^{5}\end{array}$ & 2007 & $\begin{array}{l}\text { HIV infected } \\
\text { children }\end{array}$ & $\begin{array}{l}1,180 \text { caregivers of } \\
\text { children }<15 \text { yrs } \\
103 \text { health workers }\end{array}$ & Descriptive & $\begin{array}{l}\text { Cluster sampling of } \\
\text { households } \\
\text { Convenience sampling of } \\
\text { health workers }\end{array}$ \\
\hline
\end{tabular}


1. J. van Dam, S. A. Hutchinson, "Access to treatment for HIV/AIDS: Report of a meeting of international experts: 12-13 June 2001," Horizons Report (Washington, DC: Population Council, 2002).

2. Community Medicine, Chiang Mai University et al., "A rapid situation analysis of the access to care project in northern Thailand," Horizons Final Report (Washington, DC: Population Council, 2004).

3. A. Sarna et al., "Examining adherence and sexual behavior among patients on antiretroviral therapy in India," Horizons Final Report (Washington, DC: Population Council, 2006).

4. A. Sarna et al., "Adherence to antiretroviral therapy and its principal determinants amongst HIV infected patients in India," Indian Journal of Medical Research 127: 28-36 (2008).

5. K. Kiragu et al., "If you build it, will they come? Kenya Healthy Start Pediatric HIV Study: A diagnostic study investigating barriers to HIV treatment and care among children," Horizons Final Report (Washington, DC: Population Council, 2008).

6. M. Desiree et al., "Exploring current practices in Pediatric ARV Rollout and Integration with early childhood programs in South Africa: A rapid situation analysis," Horizons Final Report (Washington, DC: Population Council, 2006).

7. V. S. Mahendra et al., "Continuum of care for HIV-positive women accessing programs to prevent parent to child transmission: Findings from India," Horizons Final Report (Washington, DC: Population Council, 2007).

8. P. Munyao et al. "How feasible is a DAART strategy to promote adherence to ART? Lessons from Mombasa, Kenya," Horizons Research Update (Nairobi: Population Council, 2005).

9. A. Sarna et al., "Acceptability of a modified directly observed therapy approach to improve adherence to antiretroviral therapy," Horizons Research Summary (Washington, DC: Population Council, 2004).
10. Horizons/Population Council, International Centre for Reproductive Health and Coast Province General Hospital, Mombasa, Kenya, Adherence to Antiretroviral Therapy in Adults: A Guide for Trainers (Nairobi: Population Council, 2004).

11. A. Sarna et al., "Promoting adherence to antiretroviral therapy through a directly administered antiretroviral therapy strategy in Mombasa, Kenya," Horizons Research Summary (Nairobi: Population Council, 2007).

12. S. Chariyalertsak et al., "A peer education intervention to reduce drop-outs and increase adherence-rates among persons living with AIDS on antiretroviral therapy in Northern Thailand," Horizons Research Summary (Washington, DC: Population Council, unpublished).

13. F. Samuels et al. "Engaging communities in supporting HIV prevention and adherence to antiretroviral therapy in Zambia," Horizons Research Summary (Washington, DC: Population Council, 2008).

14. B. E. Berger, C. E. Ferrans, F. R. Lashley, "Measuring stigma in people with HIV: Psychometric assessment of the HIV stigma scale," Research in Nursing and Health 24 (6): 518-529 (2001).

15. S. Kaai et al., "Changes in stigma among a cohort of people on antiretroviral therapy: Findings from Mombassa, Kenya," Horizons Research Summary (Nairobi: Population Council, 2007).

16. A. Sarna et al., "Does being treated with HAART affect the sexual risk behavior of people living with HIV/AIDS? Insights from Mombasa, Kenya," Horizons Research Update (Nairobi: Population Council, 2005).

17. A. Sarna et al. "Sexual risk behaviour and HAART: A comparative study of HIV infected persons on HAART and on preventive therapy in Kenya," International Journal of STD and AIDS 19 (2): 85-89 (2008).

18. S. Luchters et al., "Sexual risk behaviors of HIV positive persons receiving antiretroviral therapy in Mombasa, Kenya: findings from a longitudinal follow up," Horizons Research Summary (Nairobi: Population Council, 2007). 
19. P. Oberdopher et al., "Changes in sexual behavior of people living with HIV after 12 months of antiretroviral therapy: Experiences from Thailand" (paper presented at XVI International AIDS Conference, Toronto, Canada, 13-18 August 2006).

20. Adult AIDS Clinical Trials Group. NIAID. Baseline and follow up adherence module available at https://www.fstrf.org/apps/cfmx/apps/actg/html/ QOLForms/index.html

21. A. T. Beck, R. A. Steer, G. K. Brown, Beck Depression Inventory-II Manual (San Antonio, TX: Psychological Corporation, 1996).

22. NIAID Adult AIDS Clinical Trials Group. NIAID. HR-QOL Module available at https://www. fstrf.org/apps/cfmx/apps/actg/html/QOLForms/ index.html

23. A. W. Wu et al., "Evidence for reliability, validity and usefulness of the Medical Outcomes Study HIV Health Survey (MOS-HIV)," Quality of Life Research 6 (6): 481-93 (1997).

24. P. T. Nieuwkerk, F. J. Oort, "Self-reported adherence to antiretroviral therapy for HIV-1 infection and virologic response," Journal of Autoimmune Deficiency Syndromes 38 (4): 445-448 (2005).

25. H. Liu et al., "A comparison study of multiple measures of adherence to HIV protease inhibitors," Annals of Internal Medicine 134 (10): 968-977 (2001).

26. UNAIDS. "2004 report on the global AIDS epidemic: 4th global report" (Geneva: UNAIDS, 2004).

27. F. L. Altice et al., "Superiority of directly administered antiretroviral therapy over self-administered therapy among HIV-infected drug users: a prospective, randomized, controlled trial," Clinical Infectious Diseases 45 (6): 770-778 (2007).

28. F. L. Altice et al., "Developing a directly administered antiretroviral therapy intervention for HIVinfected drug users: implications for program replication," Clinical Infectious Diseases 38 (Suppl 5): S376-387 (2004).

29. G. E. Macalino et al., "Modified directly observed therapy for the treatment of HIV-seropositive substance users: lessons learned from a pilot study," Clinical Infectious Diseases 38 (Suppl 5): S393-397 (2004).

30. M. Fischl, "Directly observed therapy for HIV therapy in corrections: Ready or not?" (paper presented at the 8th Conference of Retroviruses and Opportunistic Infections, Chicago, Illinois, February 4-8, 2001.
31. D. A. Wohl et al., "Adherence to directly observed antiretroviral therapy among human immunodeficiency virus-infected prison inmates," Clinical Infectious Diseases 36 (12): 1572-1576 (2003).

32. A. R. Wohl et al., "A randomized trial of directly administered antiretroviral therapy and adherence case management intervention," Clinical Infectious Diseases 42 (11): 1619-1627 (2006).

33. C. R. Pearson et al., "Modified directly observed therapy to facilitate highly active antiretroviral therapy adherence in Beira, Mozambique. Development and implementation," Journal of Acquired Immune Deficiency Syndromes 43 (Suppl 1): S134-141 (2006).

34. C. J. Gill et al., "No room for complacency about adherence to antiretroviral therapy in sub-Saharan Africa," AIDS 19 (12): 1243-1249 (2005).

35. A. G. Bakari et al., "Antiretroviral therapy induced diabetes in a Nigerian," African Health Sciences 7 (3): 133-135 (2007).

36. H. Wand et al., "Metabolic syndrome, cardiovascular disease and type 2 diabetes mellitus after initiation of antiretroviral therapy in HIV infection," AIDS 21 (18): 2445-2453 (2007).

37. R. G. Jain et al., "Metabolic complications associated with antiretroviral therapy," Antiviral Research 51 (3): 151-177 (2001).

38. WHO. "Towards universal access: Scaling up priority HIV AIDS interventions in the health sector, Progress report April 2007" (Geneva: World Health Organization, 2007).

39. Clinton Foundation HIV/AIDS Initiative (CHAI). www.clintonfoundation.org

40. R. Miller et al., The Situation Analysis Approach to assessing family planning and reproductive health services: A Handbook (Population Council: New York, 1997).

41. WHO. "Towards universal access: Scaling up priority HIV/AIDS interventions in the health sector, Progress report September 2009" (Geneva: World Health Organization, 2009).

42. L. Ndholvu et al., "Reproductive health services in KwaZulu Natal, South Africa: A situation analysis study focusing on HIV/AIDS services," Horizons Final Report (Washington, DC: Population Council, 2003).

43. L. Ndhlovu, T. Maphanga, L. Madikizela, "Exploring models of delivering antiretroviral therapy and integration of ART with TB services," Horizons Final Report (Washington, DC: Population Council, unpublished). 


\section{ACKNOWLEDGEMENTS}

The Horizons research studies reviewed in this synthesis were conducted in collaboration with local implementing partners and research partners, whose cooperation and input were vital. Special thanks are extended to: International Centre for Reproductive Health, Kenya; Coast Province General Hospital, Mombasa, Kenya; Elizabeth Glazer Pediatric AIDS Foundation, Kenya; Diocese of Nairobi Eastern Deanery AIDS Relief Program, Kenya; Kenya Network of Positive women with AIDS; Christian Health Association of Kenya; Northern Railway Hospital, India; Employees State Insurance Corporation, India; Ruby Hall Clinic, India; Freedom Foundation, India; Social Awareness Service Organization, India; Ministry of Public Health, Thailand; Chiang Mai University, Thailand; International HIV/AIDS Alliance, Zambia and UK; Institute of Economic and Social Research (INESOR), Zambia; University of Cape Town, South Africa; KwaZulu Natal Department of Health, South Africa. Thanks to Gina Duclayan and Hena Khan for editing and Sherry Hutchinson for layout. 
$16 \&$ Access to Antiretroviral Therapy 
Authors: Avina Sarna, Population Council, New Delhi, India; Scott Kellerman, Population Council, New York, New York
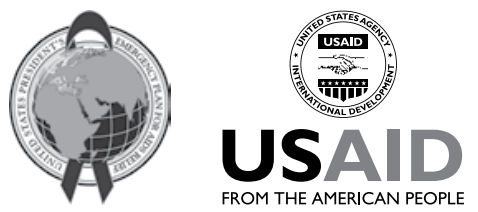

This study and final report were made possible by the President's Emergency Plan for AIDS Relief and the generous support of the American people through the United States Agency for International Development (USAID) under the terms of Cooperative Agreement No. HRNA-00-97-00012-00. The contents are the responsibility of the Horizons Program and do not necessarily reflect the views of USAID or the United States Government.

Published in May 2010.

(2) Population Council

The Population Council is an international, non-profit, nongovernmental institution that seeks to improve the well-being and reproductive health of current and future generations around the world and to help achieve a humane, equitable, and sustainable balance between people and resources. The Council conducts biomedical, social science, and public health research and helps build research capacities in developing countries. Established in 1952, the Council is governed by an international board of trustees. Its New York headquarters supports a global network of regional and country offices.

Copyright (C) 2010. The Population Council Inc.

Suggested citation: Sarna, Avina and Scott Kellerman. 2010. "Looking back, moving forward: Access to antiretroviral therapy for HIV infected adults and children in developing countries: Horizons studies 2002 to 2008," Horizons Synthesis Background Papers. Washington, DC: Population Council.

This document may be reproduced in whole or in part without permission of the Population Council provided full source citation is given and the reproduction is not for commercial purposes. 


USAID

Population Council

HIV and AIDS Program

4301 Connecticut Ave NW, Suite 280

Washington, DC 20008

Tel: 202-237-9400

Fax: 202-237-8410

pubinfo@popcouncil.org 